\title{
REGIONAL ASPECTS OF V4 COUNTRIES' ECONOMIC DEVELOPMENT OVER A MEMBERSHIP PERIOD OF 15 YEARS IN THE EUROPEAN UNION ${ }^{1}$
}

\author{
Peter Čajka², Josef Abrhám ${ }^{3}$
}

\begin{abstract}
It has been 15 years since the V4 countries joined the EU, during which individual states have undergone significant economic development. However, the dynamics of individual countries, the economic results achieved and, above all, the intra-regional development are very diverse. GDP per capita was chosen as a reference object for the analysis of their economic development, both at national and regional level. From a methodological point of view at the regional level, we analyse NUTS 2 regions where we can obtain relevant indicators within Eurostat. The aim is thus to capture and analyse GDP per capita economic development, to compare national differences over the past 14 years, to identify possible common development trends or differences. To better understand national economic developments, we will also analyse the level of individual regions as significant interregional differences in these countries have persisted over a long term. The aim is to identify whether the current development is leading to a greater deepening of interregional differences or, on the contrary, to levelling of them.
\end{abstract}

KEY WORDS: GDP per capita, V4, NUTS 2, Eurostat, economic crisis

\section{INTRODUCTION}

Over the past decades, individual economies have undergone significant changes. It was mainly the transition from a centrally planned to a market economy, the implementation of major reforms, but also the accession of the V4 countries to the European Union and in the case of the Slovak Republic, the adoption of a single European currency.

In 2019, it has been 15 years of membership of the 10 Member States that joined on 1 May 2004 as part of the largest enlargement of the

\footnotetext{
${ }^{1}$ This research was supported by the project VEGA No. 1/0720/19

${ }^{2}$ Assoc. Prof. Peter Čajka, PhD., Faculty of Political Sciences and International Relations Matej Bel University, E-mail: peter.cajka@umb.sk.

${ }^{3}$ Assoc. Prof. Josef Abrhám, PhD., Metropolitan University Prague, E-mail: josef.abrham@ mup.cz.
} 
European Union. During this period, individual states have gone through various stages of development, marked by determinants of national political developments, but also by external factors such as in the context of the global economic crisis that erupted in 2008 and resulted in one of the world's largest post-war recessions. The global financial and economic crisis has also been reflected in the economic performance of individual countries in the world, in unemployment rates and also in inflation. We analyse the development and level of both national and regional GDP per capita at NUTS 2 level. The aim of the paper is to compare the development of GDP between individual V4 states as well as between regions and to identify whether the current economic development in the regions is consequently leading to deepening of interregional differences (regional divergence) or vice versa (regional convergence). In this case, this is a theoretical concept that has been encountered for decades. The fundamental difference between the two groups is whether their authors attach greater importance to the mechanisms and processes leading to levelling or, on the contrary, to the more differentiating processes and mechanisms. (see more Blažek, Uhlî́r, 2002; Dawkins, 2003; Čajka, Rýsová, 2008; Buček, Rehák, Tvrdoň, 2010; Kováč, Kováč Gerulová, Buček, 2011; Stilianos, 2012; Antonescu, 2015; and others). In our article we used the comparison method as well as the analysis method.

\section{GDP PER CAPITA OF THE V4 COUNTRIES}

Over the past 15 years, individual V4 countries have undergone different economic developments. When we were analysing the values of regional GDP per capita, all countries recorded an increase in 2004 - 2017. Based on the eurostat.eu data, Hungary recorded the lowest dynamics of national GDP growth per capita in the period under review. In 2007, regional GDP per capita was $60 \%$ of the EU average. At present (2017) this figure is 68\% of the EU average, which is also the lowest among the V4 countries. Thus, in 14 years, the Hungarian economy has grown by $13 \%$. At the same time, as the only V4 country, it does not show the lowest GDP per capita average value in 2004, i.e. at the time of EU integration, but only in 2007. The second slowest GDP per capita growth in relative terms to the EU average was reported by the Czech Republic, which recorded a 14\% increase in GDP per capita in the reporting period, from $78 \%$ in 2004 to the current $89 \%$ of the EU average in 2017. At the same time, it is the highest GDP per capita within the V4 countries. The Czech Republic, at the same time, achieves the 
highest average GDP per capita in all countries of the former Eastern Bloc. By contrast, Poland recorded the second highest dynamic growth of GDP in the V4 countries. In the case of this country we must also conclude that the indicators available from Eurostat were from 2009, when the GDP per capita was only $57 \%$, which is significantly the lowest in 2009 compared to the other V4 states. In 2017, GDP value reached $70 \%$ of the EU average GDP. The growth rate of Polish GDP between 2009 and 2017 is 23\% of the EU average. At the same time, Poland has been achieving higher GDP values in comparison with Hungary since 2015, bringing Hungary to the last place in the $\mathrm{V} 4$ and stagnating in recent years.

Significantly highest rate of GDP growth per capita in relative terms to the EU average since joining the EU among the V4 countries recorded Slovakia. Based on the Eurostat statistical indicators, Slovakia shows the lowest value compared to Hungary and the Czech Republic, at 57\% of the average GDP per capita. In the following period, however, Slovakia recorded the highest dynamics of economic growth, which was also reflected in GDP per capita. Between 2004 and 2008, there was an increase of 14\% of GDP, from 57\% to $71 \%$, which represents the greatest dynamics in the period under review among all V4 countries. The current value of the Slovak GDP per capita is $76 \%$, which is the second highest value among the V4 countries and at the same time the biggest difference between these states at 33\%. Based on the Eurostat statistical indicators, Slovakia shows the lowest value compared to Hungary and the Czech Republic, at 57\% of the average GDP per capita. In the following period, however, Slovakia recorded the highest dynamics of economic growth, which was also reflected in GDP per capita. Between 2004 and 2008, there was an increase of $14 \%$ of GDP, from $57 \%$ to $71 \%$, which represents the greatest dynamism in the period under review among all V4 countries. The current value of the Slovak GDP per capita is $76 \%$, which is the second highest value among the V4 countries and at the same time the biggest difference between these states at 33\%. At the same time, however, it must be stated that in recent years Slovakia has been stagnating, since 2014 when three years in a row shows a constant value of $77 \%$ of the average GDP per capita and even in the last year a decrease to the already mentioned 76\%. Even, from 2016, compared to other V4 countries, Slovakia is the only one to show a decline in GDP (see Table 1 and Graph 1).

For a more detailed analysis of the economic development of individual V4 countries, we have chosen the NUTS 2 level of GDP per capita as the reference framework. 
Table 1: National (V4) GDP per capita 2004 - 2017

\begin{tabular}{|l|r|r|r|r|r|r|r|r|r|r|r|r|r|r|c|}
\hline country & $\mathbf{2 0 0 4}$ & $\mathbf{2 0 0 5}$ & $\mathbf{2 0 0 6}$ & $\mathbf{2 0 0 7}$ & $\mathbf{2 0 0 8}$ & $\mathbf{2 0 0 9}$ & $\mathbf{2 0 1 0}$ & $\mathbf{2 0 1 1}$ & $\mathbf{2 0 1 2}$ & $\mathbf{2 0 1 3}$ & $\mathbf{2 0 1 4}$ & $\mathbf{2 0 1 5}$ & $\mathbf{2 0 1 6}$ & $\mathbf{2 0 1 7}$ & increase 2004 - 2017 \\
\hline Czechia & 78 & 79 & 79 & 82 & 84 & 85 & 83 & 83 & 82 & 84 & 86 & 87 & 88 & 89 & $\mathbf{1 4 \%}$ \\
\hline Hungary & 61 & 62 & 61 & 60 & 63 & 64 & 65 & 66 & 66 & 67 & 68 & 68 & 67 & 68 & $\mathbf{1 3 \%}$ \\
\hline Poland & & & & & & 57 & 63 & 65 & 66 & 67 & 67 & 69 & 68 & 70 & $\mathbf{2 3 \%}$ \\
\hline Slovakia & 57 & 60 & 63 & 67 & 71 & 71 & 74 & 74 & 76 & 76 & 77 & 77 & 77 & 76 & $\mathbf{3 3 \%}$ \\
\hline
\end{tabular}

Source: Processed by authors, based on Regional GDP per capita of the EU, Eurostat

Graph 1: National (V4) GDP per capita 2004 - 2017

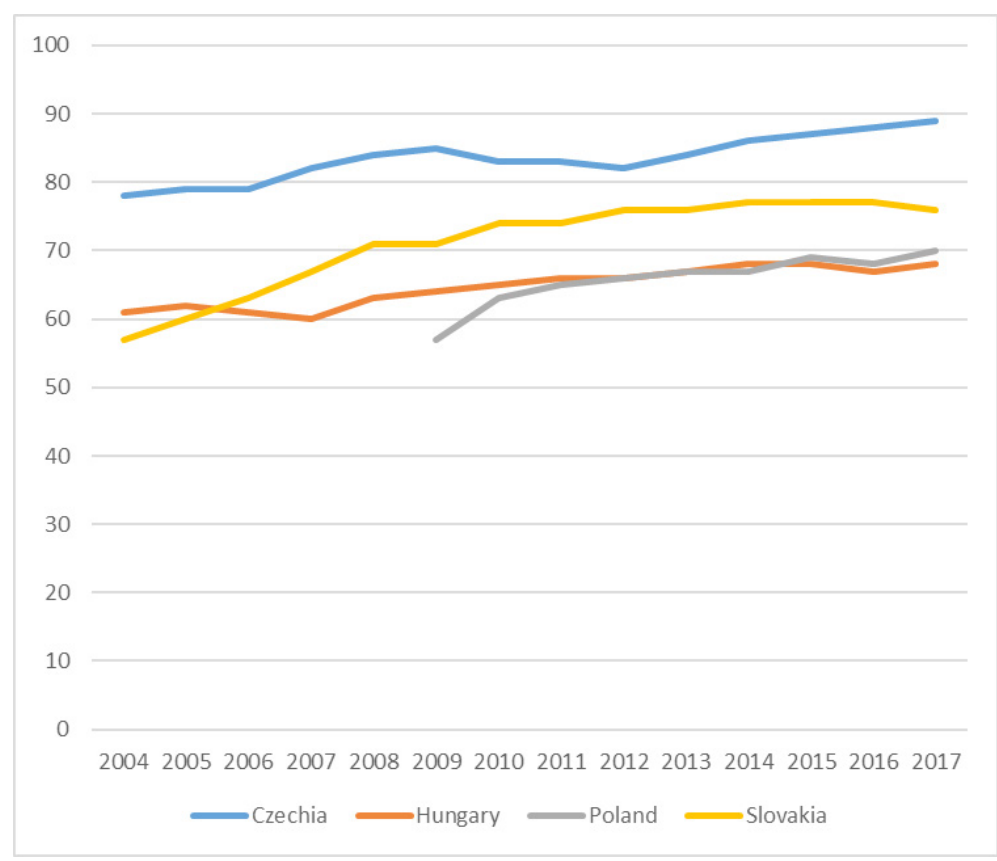

Source: Processed by authors, based on Regional GDP per capita of the EU, Eurostat

\section{Regional aspects of Czech Republic's economic development}

Czech Republic consists of 8 regions at NUTS 2 level. The most developed region of the Czech Republic is the Prague Region. At the same time, it is currently the 7th most advanced European region, with 187\% of GDP per capita in 2017, released by Eurostat, the European Union's statistical office. (Eurostat, 2019) (see Table 2). At the same time, it is the highestranking region in the former Central and Eastern Europe. In the comparison of the dynamics of development and changes in the period under review, 
the Prague region experienced the same dynamics of change as the Czech Republic itself, namely the difference between 2004 and 2017 by $14 \%$. The same dynamics of change were also seen in the North East region. Central Moravia recorded the highest dynamics of change by $120 \%$. On the other hand, the Midwest saw the same change, with GDP in 2017 at the same level as in 2004 , at $63 \%$ of GDP per capita average. The smallest interregional difference between NUTS 2 regions was in 2004 and amounted to $269 \%$. On the contrary, the largest interregional difference in the Czech regions in 2017 was at the level of $297 \%$. It follows the above findings that the economic disparities between the Czech regions have been steadily increasing over the whole period, which is mainly due to the dynamics of the development of the Prague region. However, the overall gap between the smallest interregional difference of 2004 (269\%) and the largest interregional difference of 2017 $(297 \%)$ is only $10 \%$ different. At present, as well as for the entire period under review, no other region, except the Prague region, is higher than the GDP of the Czech Republic (see Table 3 and Graph 2).

Table 2: Regional GDP per capita in the EU in 2017 (in PPS, EU28 = 100)

\begin{tabular}{|c|c|c|c|c|c|}
\hline \multicolumn{3}{|c|}{ The highest: } & \multicolumn{3}{c|}{ The lowest: } \\
\hline 1. & $\begin{array}{c}\text { Inner London - West } \\
(\mathrm{UK})^{*}\end{array}$ & 626 & 1. & North-West (BG) & 31 \\
\hline 2. & Luxembourg (LU)* & 253 & 2. & North-Central (BG) & 34 \\
\hline 3. & Southern (IE)* & 220 & - & Mayotte (FR) & 34 \\
\hline 4. & Hamburg (DE) & 202 & 4. & South-Central (BG) & 35 \\
\hline 5. & Brussels Region (BE)* & 196 & 5. & North-East (BG) & 39 \\
\hline 6. & Eastern \& Midland (IE) & 189 & - & North-East (RO) & 39 \\
\hline 7. & Prague (CZ)* & 187 & 7. & South-East (BG) & 43 \\
\hline 8. & Bratislava (SK)* & 179 & - & North Great Plain (HU) & 43 \\
\hline 9. & Upper Bavaria (DE) & 177 & 9. & South Transdanubia (HU) & 45 \\
\hline 10. & Île-de-France (FR)* & 176 & - & South-West Oltenia (RO) & 45 \\
\hline 11. & $\begin{array}{c}\text { Inner London - East } \\
\text { (UK)* }\end{array}$ & 168 & 11. & $\begin{array}{c}\text { East Macedonia, Thrace } \\
\text { (EL) }\end{array}$ & 46 \\
\hline 12. & North Holland (NL)* & 167 & - & North Hungary (HU) & 46 \\
\hline 13. & Capital (region) (DK)* & 166 & 13. & Epirus (EL) & 48 \\
\hline
\end{tabular}




\begin{tabular}{|c|c|c|c|c|c|}
\hline- & Stockholm (SE)* & 166 & - & North Aegean (EL) & 48 \\
\hline 15. & Stuttgart (DE) & 159 & - & South Great Plain (HU) & 48 \\
\hline 16. & Darmstadt (DE) & 157 & - & Lubelskie (PL) & 48 \\
\hline 17. & Bremen (DE) & 155 & 17. & West Macedonia (EL) & 49 \\
\hline- & Utrecht (NL) & 155 & - & French Guiana (FR) & 49 \\
\hline 19. & Warsaw-Capital (PL)* & 152 & - & $\begin{array}{c}\text { Warmińsko-Mazurskie } \\
\text { (PL) }\end{array}$ & 49 \\
\hline 20. & Vienna (AT)* & 151 & - & Podkarpackie (PL) & 49 \\
\hline- & Salzburg (AT) & 151 & - & \\
\hline \multicolumn{7}{|c|}{ Capital region } \\
\hline
\end{tabular}

Source: Regional GDP per capita ranged from 31\% to $626 \%$ of the EU average in 2017, Eurostat

Table 3: Czech (country/NUTS 2) GDP per capita 2004 - 2017

\begin{tabular}{|l|r|r|r|r|r|r|r|r|r|r|r|r|r|r|r|}
\hline country / NUTS 2 & $\mathbf{2 0 0 4}$ & $\mathbf{2 0 0 5}$ & $\mathbf{2 0 0 6}$ & $\mathbf{2 0 0 7}$ & $\mathbf{2 0 0 8}$ & $\mathbf{2 0 0 9}$ & $\mathbf{2 0 1 0}$ & $\mathbf{2 0 1 1}$ & $\mathbf{2 0 1 2}$ & $\mathbf{2 0 1 3}$ & $\mathbf{2 0 1 4}$ & $\mathbf{2 0 1 5}$ & $\mathbf{2 0 1 6}$ & $\mathbf{2 0 1 7}$ & increase 2004 - 2017 \\
\hline Czechia & 78 & 79 & 79 & 82 & 84 & 85 & 83 & 83 & 82 & 84 & 86 & 87 & 88 & 89 & $\mathbf{1 4 \%}$ \\
\hline Praha & 164 & 169 & 170 & 179 & 183 & 183 & 179 & 175 & 172 & 174 & 175 & 183 & 183 & 187 & $\mathbf{1 7 \%}$ \\
\hline Strední Cechy & 75 & 73 & 75 & 78 & 79 & 77 & 73 & 75 & 75 & 75 & 79 & 78 & 81 & 84 & $12 \%$ \\
\hline Jihozápad & 72 & 73 & 73 & 73 & 71 & 75 & 73 & 73 & 72 & 74 & 77 & 76 & 77 & 77 & $7 \%$ \\
\hline Severozápad & 63 & 64 & 63 & 64 & 65 & 68 & 64 & 64 & 63 & 63 & 63 & 64 & 62 & 63 & \\
\hline Severovýchod & 66 & 67 & 66 & 68 & 68 & 69 & 68 & 68 & 67 & 68 & 71 & 71 & 73 & 75 & $\mathbf{1 4 \%}$ \\
\hline Jihovýchod & 68 & 69 & 69 & 73 & 75 & 76 & 74 & 75 & 76 & 79 & 81 & 81 & 81 & 81 & $\mathbf{1 9 \%}$ \\
\hline Strední Morava & 61 & 61 & 61 & 63 & 66 & 68 & 66 & 67 & 67 & 68 & 72 & 71 & 72 & 73 & $\mathbf{2 0 \%}$ \\
\hline Moravskoslezsko & 63 & 67 & 65 & 68 & 70 & 69 & 69 & 71 & 71 & 70 & 72 & 72 & 73 & 74 & $18 \%$ \\
\hline & & & & & & & & & & & & & & \\
\hline diference top-down & $269 \%$ & & & & & & & & & & & & & $297 \%$
\end{tabular}

Source: Processed by authors, based on Regional GDP per capita of the EU, Eurostat 
Graph 2: Czech (country/NUTS 2) GDP per capita 2004 - 2017

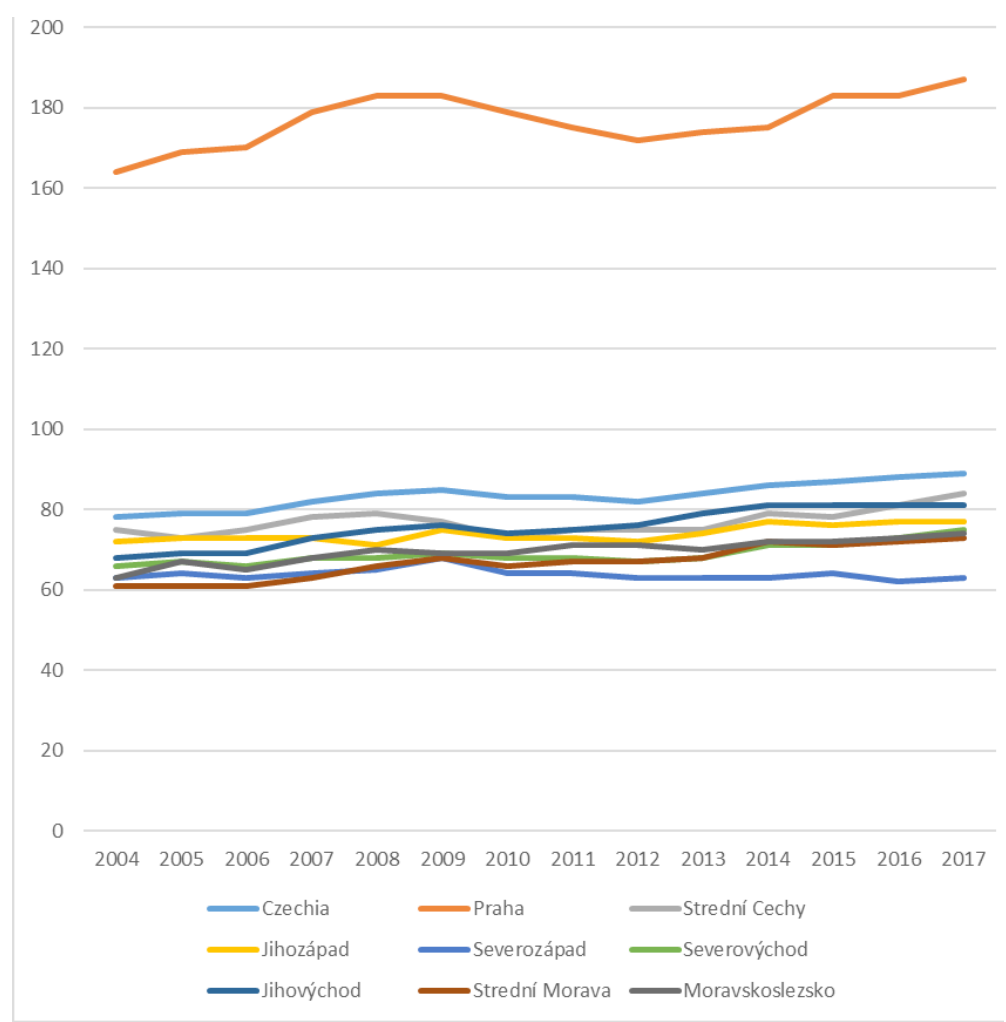

Source: Processed by authors, based on Regional GDP per capita of the EU, Eurostat

\section{Regional aspects of Hungary's economic development}

Hungary consists of 7 regions at NUTS 2 level. The most advanced region of Hungary is Közép-Magyarországktor, which currently reaches 104\% of the average GDP per capita. This central Hungarian region only reached the European average of $100 \%$ or more in 2005 . Even though it is the strongest region in Hungary, in the monitored period of 2004 - 2017, it recorded one of the lowest economic growths at only $6 \%$, which is less than the Hungarian average for the same period - $12 \%$. The dynamics of the other Hungarian regions are also very close to the Hungarian difference. The region with the lowest dynamics is Dél-Dunántúl with an increase of 5\%, while the highest dynamics were recorded in the Észak-Magyarország region at 15\%. Even though it is the strongest region in Hungary, in the monitored period of 2004 
- 2017, it recorded one of the lowest economic growths at only 6\%, which is less than the Hungarian average for the same period - $12 \%$. The dynamics of the other Hungarian regions are also very close to the Hungarian difference. The region with the lowest dynamics is Dél-Dunántúl with an increase of $5 \%$, while the highest dynamics were recorded in the Észak-Magyarország region by $15 \%$.

The smallest interregional difference between NUTS 2 regions was in 2017 and amounted to $242 \%$. On the contrary, the biggest interregional difference in the Hungarian regions in 2009 was at the difference of $278 \%$. These findings suggest that the economic differences expressed in GDP per capita between Hungarian regions have been steadily decreasing since 2009. On the other hand, it should be pointed out that 4 Hungarian regions are in the last twenty of economically least developed regions at NUTS 2 level (see Table 2), within all 281 European regions. At the same time, these Hungarian regions represent the least developed regions within the V4 countries. The overall difference between the smallest interregional difference in 2017 (242\%) and the largest interregional difference in 2009 $(278 \%)$ is $14 \%$. Currently, two Hungarian regions have a GDP per capita higher than the Hungarian average. Of course, the Közép-Magyarország region has a dominant position, and the Nyugat-Dunántúl region, which is higher than the Hungarian average with the exception of the 2007 - 2010 period, is the second largest, with the difference dynamically rising after 2014. On the other hand, the strongest region of Közép -Magyarország since 2014 as one of the few of all Hungarian regions shows a smaller economic downturn (see Table 4 and Graph 3).

Table 4: Hungary (country/NUTS 2) GDP per capita 2004 - 2017

\begin{tabular}{|l|r|r|r|r|r|r|r|r|r|r|r|r|r|r|c|}
\hline country / NUTS 2 & $\mathbf{2 0 0 4}$ & $\mathbf{2 0 0 5}$ & $\mathbf{2 0 0 6}$ & $\mathbf{2 0 0 7}$ & $\mathbf{2 0 0 8}$ & $\mathbf{2 0 0 9}$ & $\mathbf{2 0 1 0}$ & $\mathbf{2 0 1 1}$ & $\mathbf{2 0 1 2}$ & $\mathbf{2 0 1 3}$ & $\mathbf{2 0 1 4}$ & $\mathbf{2 0 1 5}$ & $\mathbf{2 0 1 6}$ & $\mathbf{2 0 1 7}$ & increase 2004 - 2017 \\
\hline Hungary & 61 & 62 & 61 & 60 & 63 & 64 & 65 & 66 & 66 & 67 & 68 & 68 & 67 & 68 & $\mathbf{1 2 \%}$ \\
\hline Közép-Magyarország & 98 & 101 & 101 & 100 & 104 & 108 & 107 & 107 & 107 & 108 & 106 & 104 & 102 & 104 & $6 \%$ \\
\hline Közép-Dunántúl & 57 & 58 & 56 & 55 & 56 & 53 & 56 & 58 & 57 & 60 & 62 & 63 & 63 & 63 & $\mathbf{1 1 \%}$ \\
\hline Nyugat-Dunántúl & 63 & 61 & 62 & 59 & 61 & 60 & 64 & 67 & 66 & 68 & 73 & 73 & 73 & 72 & $\mathbf{1 4 \%}$ \\
\hline Dél-Dunántúl & 43 & 43 & 41 & 40 & 42 & 44 & 44 & 44 & 45 & 45 & 45 & 44 & 44 & 45 & $5 \%$ \\
\hline Észak-Magyarország & 40 & 41 & 40 & 38 & 39 & 39 & 39 & 40 & 39 & 41 & 43 & 45 & 44 & 46 & $\mathbf{1 5 \%}$ \\
\hline Észak-Alföld & 40 & 40 & 39 & 38 & 39 & 41 & 41 & 43 & 42 & 42 & 44 & 43 & 42 & 43 & $8 \%$ \\
\hline Dél-Alföld & 43 & 43 & 41 & 40 & 42 & 42 & 42 & 44 & 45 & 46 & 48 & 49 & 47 & 48 & $\mathbf{1 2 \%}$ \\
\hline & & & & & & & & & & & & & & & \\
\hline
\end{tabular}

Source: Processed by authors, based on Regional GDP per capita of the EU, Eurostat 
Graph 3: Hungary (country/NUTS 2) GDP per capita 2004 - 2017

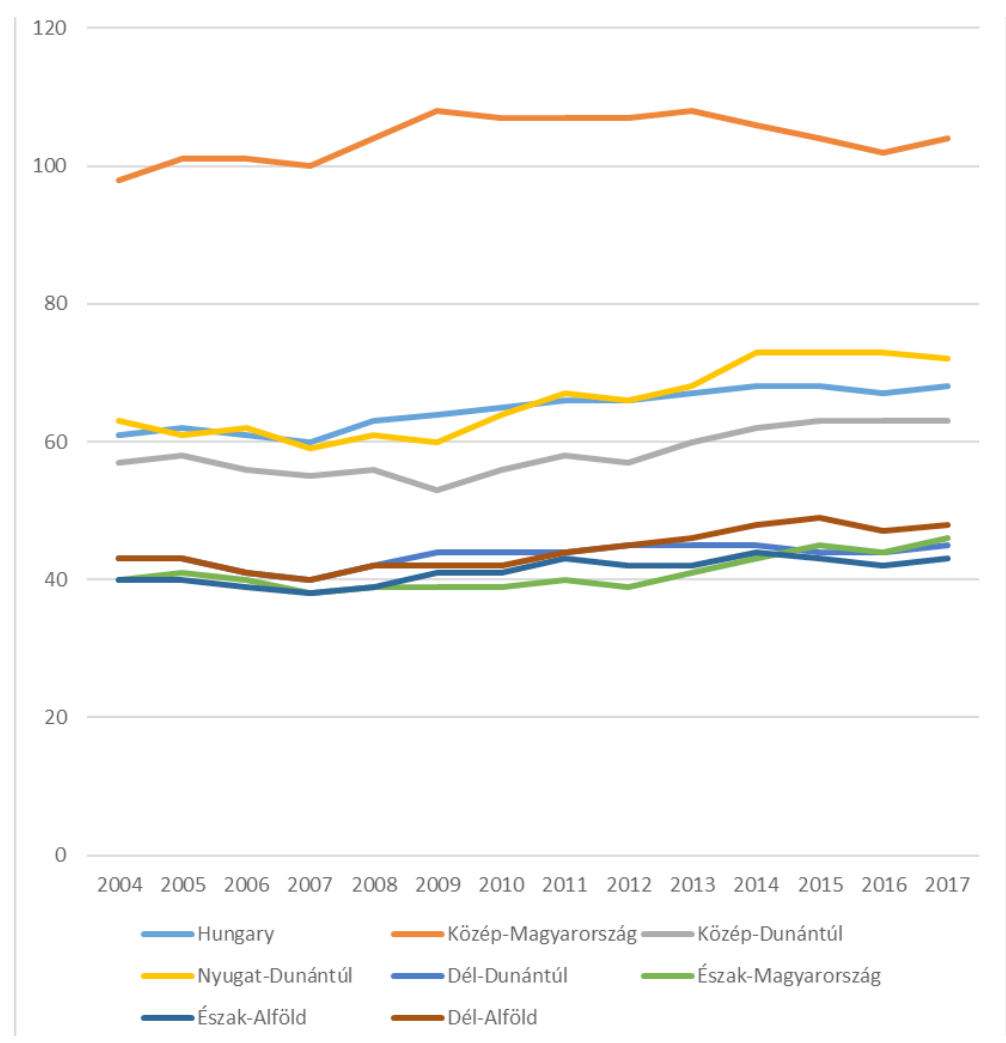

Source: Processed by authors, based on Regional GDP per capita of the EU, Eurostat

\section{Regional aspects of Poland's economic development}

Poland, according to currently valid breakdown (i.e. NUTS 2010 effective from January 1, 2012) (Commission of the EU) is divided into 16 regions at NUTS 2 level. For this reason, as well as the availability of GDP per capita values from the Eurostat database, we have processed and monitored the values since 2009, the period of last 9 years. Despite this limitation, the reference period as well as the available GDP per capita offer us sufficiently relevant information to assess the specificities of economic development.

The most developed region of Poland is the Mazowiecki region. Currently, this region reaches $12 \%$ of the average European GDP per capita. Since 2014, within Eurostat, the Mazowiecki region has been divided into two sub-regions - Warszawski stołeczny and Mazowiecki regionalny. Of course, 
within these two regions, Warszawski stołeczny region has a dominant position, which in 2017 amounts to $152 \%$ of the average European GDP per capita, which currently places it in 19th of Europe's richest regions (see Table 2).

In the comparison of the dynamics of development and the changes in the period under review, the Mazowiecki region experienced the same dynamics of change as Poland itself, and the difference between 2009 and 2017 by 23\%. Two other regions - Łódzky and Lubelsky - recorded the same dynamics.

Malopolsky region recorded the highest dynamics of change by $19 \%$. On the contrary, the smallest change was recorded in the Świętokrzysky region by $11 \%$. In general, only four regions have experienced higher dynamics of change, while up to 9 Polish regions have less dynamics of development than the Polish average of $23 \%$. At the same time, up to four Polish regions (Mazowiecky, Dolnośląsky, Wielkopolsky and Slasky) have a higher GDP per capita than the Polish average.

Interestingly, in the case of Poland, the fact that the smallest interregional difference between individual NUTS 2 regions was exactly the same in 2009 as in 2017 and amounted to $233 \%$. On the contrary, the largest interregional difference in Poland was recorded in 2011 at a level of 243\%. The overall difference between the smallest interregional difference in 2009 or 2017 (233\%) and 2011's largest interregional gap (243\%) is only 5\%. These findings suggest that the economic disparities between the Polish regions over the period are relatively balanced and that there is no significant increase in interregional differences. However, in this context, it is necessary to note that the overall economic level of the Polish regions measured by GDP per capita is very low, as evidenced by the fact that there are three Polish regions in the twenty least developed regions of all 281 European regions (see Table 5 and Graph 4).

Table 5: Poland (country/NUTS 2) GDP per capita 2009 - 2017

\begin{tabular}{|l|r|r|r|r|r|r|r|r|r|c|}
\hline country / NUTS 2 & $\mathbf{2 0 0 9}$ & $\mathbf{2 0 1 0}$ & $\mathbf{2 0 1 1}$ & $\mathbf{2 0 1 2}$ & $\mathbf{2 0 1 3}$ & $\mathbf{2 0 1 4}$ & $\mathbf{2 0 1 5}$ & $\mathbf{2 0 1 6}$ & $\mathbf{2 0 1 7}$ & increase 2009 - 2017 \\
\hline Poland & 57 & 63 & 65 & 66 & 67 & 67 & 69 & 68 & 70 & $\mathbf{2 3 \%}$ \\
\hline tódzkie & 53 & 58 & 60 & 61 & 63 & 63 & 64 & 64 & 65 & $\mathbf{2 3 \%}$ \\
\hline Mazowieckie & 91 & 102 & 107 & 105 & 107 & 108 & 109 & 109 & 112 & $\mathbf{2 3 \%}$ \\
\hline Malopolskie & 49 & 53 & 56 & 58 & 59 & 60 & 62 & 62 & 63 & $\mathbf{2 9 \%}$ \\
\hline Slaskie & 61 & 67 & 70 & 70 & 70 & 70 & 71 & 71 & 72 & $\mathbf{1 8 \%}$ \\
\hline Lubelskie & 39 & 42 & 44 & 46 & 48 & 47 & 47 & 47 & 48 & $\mathbf{2 3 \%}$ \\
\hline Podkarpackie & 39 & 42 & 44 & 46 & 48 & 48 & 49 & 48 & 49 & $\mathbf{2 5 \%}$ \\
\hline Świętokrzyskie & 45 & 47 & 49 & 49 & 49 & 49 & 50 & 49 & 50 & $\mathbf{1 1 \%}$ \\
\hline
\end{tabular}




\begin{tabular}{|l|r|r|r|r|r|r|r|r|r|l|}
\hline Podlaskie & 42 & 45 & 47 & 47 & 49 & 49 & 49 & 48 & 50 & $\mathbf{1 9 \%}$ \\
\hline Wielkopolskie & 60 & 65 & 68 & 70 & 73 & 72 & 75 & 74 & 76 & $\mathbf{2 7 \%}$ \\
\hline Zachodniopomorskie & 51 & 54 & 55 & 55 & 57 & 56 & 58 & 57 & 58 & $14 \%$ \\
\hline Lubuskie & 49 & 53 & 54 & 55 & 56 & 57 & 57 & 57 & 57 & $16 \%$ \\
\hline Dolnośląskie & 62 & 70 & 74 & 74 & 76 & 75 & 76 & 75 & 77 & $\mathbf{2 4 \%}$ \\
\hline Opolskie & 47 & 50 & 52 & 53 & 54 & 55 & 55 & 54 & 55 & $17 \%$ \\
\hline Kujawsko-Pomorskie & 49 & 52 & 54 & 53 & 56 & 55 & 56 & 56 & 56 & $14 \%$ \\
\hline Warmińsko-Mazurskie & 42 & 46 & 47 & 47 & 48 & 48 & 49 & 49 & 49 & $17 \%$ \\
\hline Pomorskie & 55 & 60 & 62 & 64 & 65 & 64 & 66 & 66 & 67 & $\mathbf{2 2 \%}$ \\
\hline & & & & & & & & \\
\hline
\end{tabular}

Source: Processed by authors, based on Regional GDP per capita of the EU, Eurostat

Graph 4: Poland (country/NUTS 2) GDP per capita 2009 - 2017

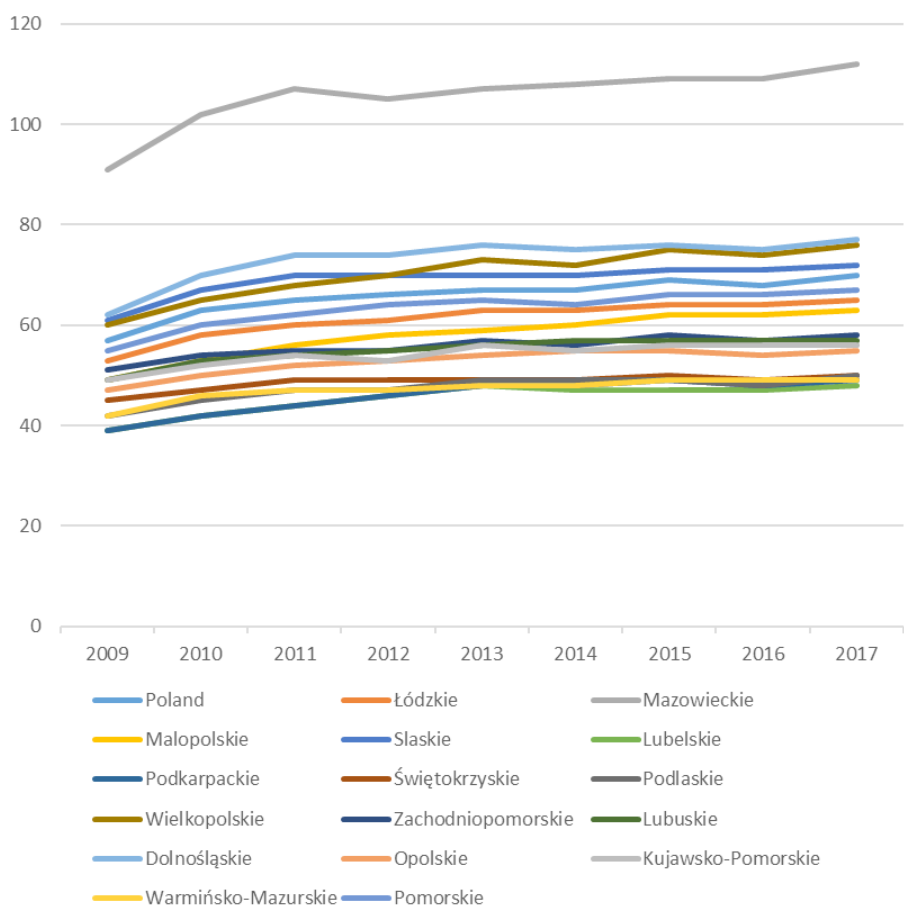

Source: Processed by authors, based on Regional GDP per capita of the EU, Eurostat

\section{Regional aspects of Slovakia's economic development}

Over the past decades, the Slovak economy has undergone many significant changes. It was mainly the transition from a centrally planned 
to a market economy, the implementation of major reforms, but also the accession of the Slovak Republic to the European Union and the adoption of a single European currency. All these changes have contributed to significant economic growth and increased country competitiveness. In the first decade of the 21st century, the Slovak Republic was among the most dynamically developing economies in Europe. Its growth was one of the fastest within the EU Member States and since 2001 it has been well above the EU average economic growth. A similar favourable trend was recorded by the indicator expressing the growth rate of GDP per capita. (Spišáková, Pétrová, 2011, p. 240)

Slovakia consists of 4 regions at NUTS 2 level. Compared to all V4 countries, Slovakia experienced the greatest dynamics of change in the 2004 - 2017 period, or more precisely economic growth by up to 33\% (2004 - 57\% and 2017 - 76\%). The most developed region of Slovakia is the Bratislava Region. At the same time, it is currently the 8 most advanced European region with a value of $179 \%$ of GDP per capita in 2017 from the date released by Eurostat, the European Union's statistical office (Eurostat, 2019) (see Table 2). At the same time, together with the Prague region, it is the highest-ranking region in the former Central and Eastern Europe.

The specificity of the Bratislava region in comparison with all analysed NUTS 2 regions within the V4 states is that the region recorded the highest economic growth rate of 147\% of GDP per capita (between $2004-129 \%$ and $2013-189 \%$ ) and currently 2017 - 179\% GDP per capita, this difference is $39 \%$. In comparison of the development dynamics and changes compared to the whole of Slovakia at the level of 33\% between 2004 and 2017, this average significantly exceeds. At the same time, the Bratislava Region is the only one above the Slovak average. Central Slovakia also experienced the same dynamics of change as the Slovak Republic (33\%). The remaining two regions in Slovakia reach a lower average, while Eastern Slovakia recorded the weakest regions in the dynamics of change at $29 \%$.

The smallest interregional difference between NUTS 2 regions was in 2004, up to $307 \%$. On the contrary, the largest interregional difference in Slovakia was recorded in 2013, up to $364 \%$. It follows from the above findings that the economic differences between the Slovak regions over the whole period reach the highest values in comparison with the other V4 countries. This is also evidenced by the overall difference between the smallest interregional difference of $2004(307 \%)$ and the largest interregional difference of 2013 (364\%), which makes a $19 \%$ difference.

At present, as well as for the whole period under review, no other region, 
except the Bratislava region, is at a higher level of GDP per capita than the average of Slovakia (see Table 6 and Graph 5).

Table 6: Slovak (country/NUTS 2) GDP per capita 2004 - 2017

\begin{tabular}{|l|r|r|r|r|r|r|r|r|r|r|r|r|r|r|c|}
\hline country / NUTS 2 & $\mathbf{2 0 0 4}$ & $\mathbf{2 0 0 5}$ & $\mathbf{2 0 0 6}$ & $\mathbf{2 0 0 7}$ & $\mathbf{2 0 0 8}$ & $\mathbf{2 0 0 9}$ & $\mathbf{2 0 1 0}$ & $\mathbf{2 0 1 1}$ & $\mathbf{2 0 1 2}$ & $\mathbf{2 0 1 3}$ & $\mathbf{2 0 1 4}$ & $\mathbf{2 0 1 5}$ & $\mathbf{2 0 1 6}$ & $\mathbf{2 0 1 7}$ & increase 2004 - 2017 \\
\hline Slovakia & 57 & 60 & 63 & 67 & 71 & 71 & 74 & 74 & 76 & 76 & 77 & 77 & 77 & 76 & $\mathbf{3 3 \%}$ \\
\hline Bratislavský kraj & 129 & 146 & 147 & 158 & 165 & 174 & 181 & 185 & 183 & 189 & 186 & 186 & 185 & 179 & $\mathbf{3 9 \%}$ \\
\hline Západné Slovensko & 54 & 57 & 62 & 65 & 68 & 66 & 69 & 71 & 72 & 72 & 73 & 71 & 71 & 70 & $30 \%$ \\
\hline Stredné Slovensko & 46 & 46 & 49 & 53 & 58 & 57 & 60 & 58 & 60 & 60 & 61 & 61 & 61 & 61 & $\mathbf{3 3 \%}$ \\
\hline Východné Slovensko & 42 & 43 & 44 & 46 & 50 & 48 & 51 & 51 & 52 & 52 & 53 & 54 & 53 & 54 & $29 \%$ \\
\hline & & & & & & & & & & & & & \\
\hline
\end{tabular}

Source: Processed by authors, based on Regional GDP per capita of the EU, Eurostat

Graph 5: Slovak (country/NUTS 2) GDP per capita2004 - 2017

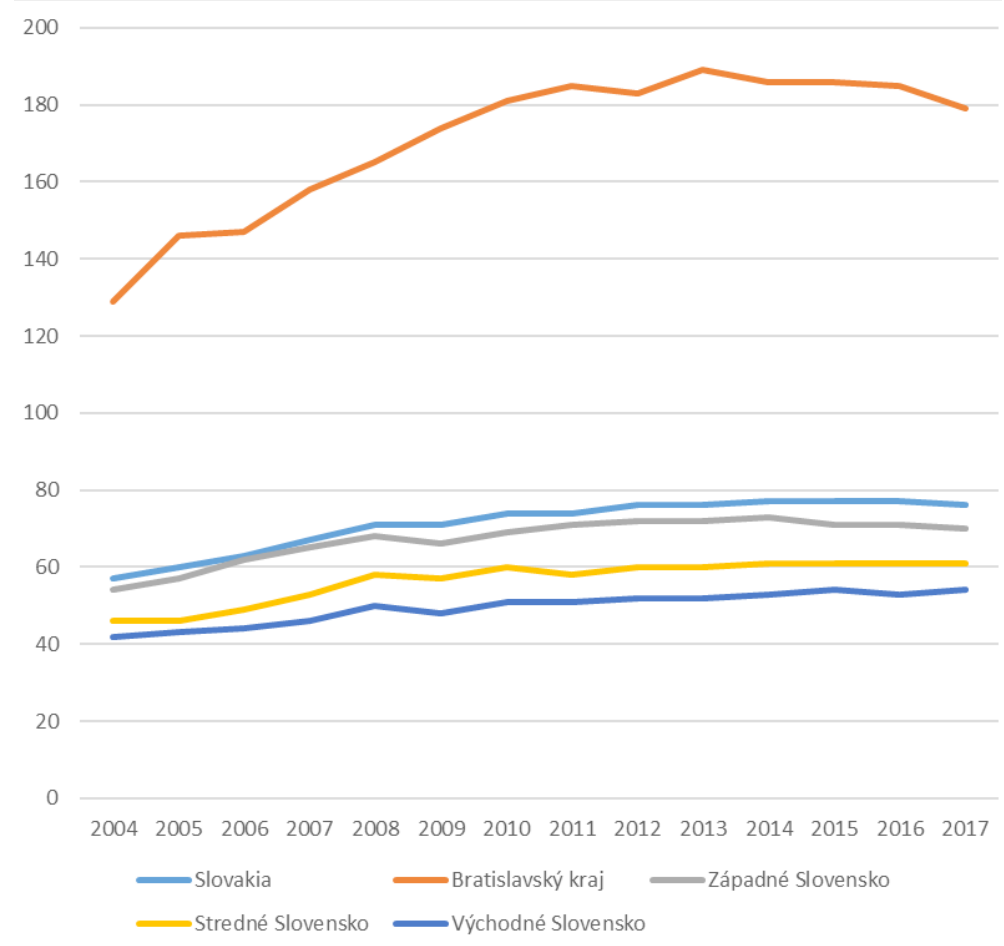

Source: Processed by authors, based on Regional GDP per capita of the EU, Eurostat 


\section{CONCLUSION}

An analysis of a total of 35 NUTS 2 regions within the V4 states yielded interesting findings. Within the national level, we have to say that in recent years all countries have recorded positive economic growth, which is reflected in a rise in GDP per capita. The Czech Republic and Poland have been recording this long-term upward trend since 2012 or, more precisely, Poland has been continuously on track since 2009. Hungary is characterized by a stagnating development over the long term and the Slovak Republic, as the only one, recorded a decline of one percentage point after a long stagnating development in the last year. On the other hand, Slovakia recorded the biggest dynamics of change already at the level of $33 \%$ in the whole monitored period. Certain factors, whether endogenous or exogenous, have an impact on such macroeconomic developments. Of the exogenous factors that could have the most significant impact, especially the negative ones, in recent years we can consider in particular the course and economic impacts of the global economic crisis of 2008, or in the following period. However, from an analysis of national GDP economic indicators per capita, it did not appear that the economic crisis had a major impact on the national economies of the $\mathrm{V} 4$ countries in the short term. In the longer term, only the Czech Republic recorded a decline in national GDP per capita in 2009-2012. The other three countries can see a positive increase each year. Within the V4 countries, the economic level of the Czech Republic needs to be emphasized, because none of the other V4 countries currently reaches the national GDP per capita average, which would correspond to the lowest GDP per capita of the Czech Republic in 2004, which was 78\% that year. The Slovak Republic is closest to this figure - 76\%. This indicator also shows the exceptional economic position of the Czech Republic compared to other V4 countries.

At the regional level, we also see a few specifics. Already from a detailed analysis of individual NUTS 2 regions at national levels, it is clear that the specificities of development in different countries vary. We see the greatest dynamics of changes at the regional level in Slovakia, at the growth rate from $29 \%$ to $39 \%$ for the whole period under review. None of the other NUTS 2 regions in other V4 countries recorded such dynamics. Only in the Polish region of Malopolskie, whose growth was just the lowest growth rate of Eastern Slovakia - 29\%. At the same time, the Bratislava Region achieved an absolute increase from all regions in the monitored period $47 \%$. On one hand, such progress can be regarded as highly positive, which 
is reflected in other economic indicators such as low unemployment rate, the highest average wage in the national economy, the attractiveness of the region for skilled labor migration, etc., on the other hand, such an economic growth in the Bratislava region causes deepening of interregional economic disparities. This phenomenon is also evidenced by data on the year-onyear differences between the most advanced and the weakest region in the country. The lowest interregional disparities for the entire period under review are in Poland in 2009 or 2017 - 233\%, then Hungary from 2017 242\%, Czech Republic - 269\% and finally Slovakia - 307\%. On the contrary, the biggest interregional differences are in Poland - 243\% (2011), Hungary - 278\% (2009), in the Czech Republic - 297\% (2017) and in Slovakia already mentioned $364 \%$ (2013). At the same time, it is clear from the graphs that interregional differences tend to be mitigated in Hungary and Poland, but this may not necessarily lead to regional equilibrium (regional convergence). On the contrary, in the case of the Czech Republic, there is a clear trend to open up "economic scissors", which results in deepening of interregional differences, the direction leading to regional divergence. In Slovakia, the last four years have seen a trend of interregional stagnation, or more precisely last year (2017), due to the decline in GDP per capita average, we can see a partial moderation of interregional differences in GDP, which does not mean achieving a regional balance. At present, we can see the most significant rate of regional divergence in Slovakia. However, it must be stated that, as in the case of the Czech Republic, the current difference in 2017 is 297\%, in Slovakia it is $332 \%$, which therefore demonstrates the greatest interregional disparities (regional divergence) within the V4 countries.

\section{REFERENCES}

ANTONESCU, D. (2015). Regional convergence - theoretical approaches. MPRA Paper No. 60288, posted 5. December 2015

BALLAS, D., DORLING, D., HENNIG, B., (2017). Analysing the regional geography of poverty, austerity and inequality in Europe: a human cartographic perspective. Regional Studies, vol. 51, no. 1, pp. 174 - 185; http://dx.doi.org/10.1080/00343404.2016.1262019.

BLAŽEK, J., UHLÍŘ, D. (2002). Teorie regionálního rozvoje - nástin, kritika, klasifikace. Univerzita Karlova, Karolinium, Praha, ISBN 8024603845

BUČEK, M., REHÁK, Š., TVRDOŇ, J. (2010). Regionálna ekonómia a politika. Bratislava: Iura Edition, ISBN 978-80-8078-361-7

ČAJKA, P., RÝSOVÁ, L. (2008). Regionálny rozvoj a regionálna politika $v$ 
kontexte poznatkovo-orientovanej spoločnosti. - 1. vyd. - Zvolen : Bratia Sabovci, 2008. - 238 s. - ISBN 978-80-89241-20-0

DAWKINS, C. J. (2003). Regional Development Theory: Conceptual

Foundations, Classic Works, and Recent Developments. Journal of Planning Literature, Vol. 18, No. 2 (November2003).

EUROSTAT, (2016). Four regions over double the EU average..., Eurostat 52/2017 - 30 March 2017, Available at: https://ec.europa.eu/eurostat/ documents/2995521/7962764/1-30032017-AP-EN.pdf/4e9 c09e5c743-41a5-afc8-eb4aa89913f6, [Accessed 21 February 2019].

GDP per capita in the EU in 2011: seven capital regions among the ten most prosperous, Eurostat 29/2014 - 27 February 2014, Available at: https://ec.europa.eu/eurostat/documents/2995521/ 5173650/1-27022014-AP-EN.PDF/a46ded44-83cf-4368-931527f96bcc3a0e, [Accessed 21 February 2019].

GDP per capita in the EU in 2013: seven capital regions among the ten most prosperous, Eurostat 90/2015 - 21 May 2015, Available at: https:// ec.europa.eu/eurostat/documents/2995521/6839731/1-21052015AP-EN.pdf/c3f5f43b-397c-40fd-a0a4-7e68e3bea8cd, [Accessed 21 February 2019].

Commission Regulation (EÚ) No. 31/2011 from 17 January 2011 Available at: http://eur-lex.europa.eu/LexUriServ/LexUriServ. do?uri=0J:L:2011:013:0003:0054:EN:PDF, [Accessed 21 February 2019]. Regional GDP per capita in 2009: seven capital regions in the ten first places, Eurostat 38/2012 - 13 March 2012, Available at: https://ec.europa. eu/eurostat/documents/2995521/5149934/1-13032012-AP-EN. PDF/642372c1-a4a5-4a24-a8b4-eb544f445182, [Accessed 21 February 2019].

Regional GDP per capita in the EU in 2010: eight capital regions in the ten first places, Eurostat 46/2013 - 21 March 2013, Available at: https:// ec.europa.eu/eurostat/documents/2995521/5160090/1-21032013AP-EN.PDF/d1ebc5cd-693f-4eb1-bb80-8279a9886b74, [Accessed 21 February 2019].

Regional GDP per capita ranged from $29 \%$ to $611 \%$ of the EU average in 2016, Eurostat 33/2018 - 28 February 2018, Available at: https:// ec.europa.eu/eurostat/documents/2995521/8700651/1-28022018BP-EN/15f5fd90-ce8b-4927-9a3b-07dc255dc42a, [Accessed 21 February 2019].

Regional GDP per capita ranged from 31\% to $626 \%$ of the EU average in 2017, Eurostat 34/2019 - 26 February 2019, Available at: https://ec.europa. 
eu/eurostat/documents/2995521/9618249/1-26022019-AP-EN.pdf/ f765d183-c3d2-4e2f-9256-cc6665909c80, [Accessed 2 March 2019].

HOLUB, T., ČIHÁK, M., (2000). Teorie růstové politiky. Praha: Vysoká škola ekonomická. ISBN 80-245-0126-0.

JANKUROVÁ, A., LJUDVIGOVÁ, I, GUBOVÁ, K. (2017). Research of the nature of leadership activities. Economics \& Sociology. Economics \& Sociology, 2017. vol. 10, no. 1. ISSN 2071-789X.

KOVÁČ, U., KOVÁČ GERULOVÁ, L., BUČEK, M. (2011). Metodologické prístupy k meraniu konvergencie, Prognostické práce, 3, 2011, č. 5

KRUGMAN, P., (1995). Development, Geography and Economic Theory. Cambridge. MIT Press. ISBN 9780262112031.

KUTSCHERAUER, A. a kol., (2010). Regionální disparity. Disparity $v$ regionálním rozvoji země, jejich pojetí, identifikace a hodnocení. Ostrava: VŠB-TU Ostrava.

MARTIN, R., (2006). A Study on the Factors of Regional Competitiveness. Draft final report for the European Commission. Brussels.

MELECKÝ, L., (2012). Evaluation of Cohesion in Visegrad Countries in Comparison with Germany and Austria by Multivariate Methods for Disparities Measurement. International Journal of Mathematical Models and Methods in Applied Sciences. vol. 6, no. 8, pp. 979-989. ISSN 19980140.

SPIŠÁKOVÁ, E., PÉTROVÁ, R. (2011). Vplyv hospodárskej krízy na vybrané makroekonomické ukazovatele v krajinách V4. Transfer inovácií 21/2011. STILIANOS, A. (2012). Neoclassical and Post-Keynesian Theories of Regional Growth and Convergence/Divergence. In: Convergence Clubs and Spatial Externalities. Advances in Spatial Science (The Regional Science Series). Springer, Berlin, Heidelberg. pp. 9-38. ISBN 978-3-642-31626-5

Twenty-one regions below half of the EU average..., Eurostat 39/2016 - 26 February 2016, Available at: https://ec.europa.eu/eurostat/ documents/2995521/7192292/1-26022016-AP-EN.pdf/602b34e8abba-439e-b555-4c3cb1dbbe6e, [Accessed 21 February 2019].

VENABLES, A. J., (2010). New Economic Geography. Part of the series The New Palgrave Economics Collection 